\title{
PROBLEM POSSING DALAM PEMBELAJARAN MATEMATIKA
}

\author{
Oleh: A. Ika Prasasti Abrar \\ Dosen Prodi Pendidikan Matematika STAIN Palopo \\ E-mail: asty math03@yahoo.co.id
}

\begin{abstract}
Abstrak:
Di Indonesia, nilai matematika berdasarkan hasil tes Trends in international Mathematics and science studi (TIMSS) 2003 yang dikoordinir oleh The international for Evaluation of Education Achievement (IEA) menempatkan mahasiswa Indonesia di peringkat 34 penguasaan matematika dan peringkat 36 penguasaan sains. Dibandingkan dengan dua Negara tetangga, Singapura dan Malaysia, posisi ini jauh tertinggal. Singapura berada pada peringkat, pertama, baik matematika maupun Sains, Malaysia peringkat 10 Matematika dan peringkat 23 bidang sains (Balitbang Depdiknas, 2004). Menurut hasil studi yang dilakukan oleh Suryanto dan Soemerset terhadap 16 SLTP pada beberapa propinsi di Indonesia juga menemukan bahwa hasil tes mata pelajaran matematika mahasiswa sangat rendah, utamanya pada soal cerita matematika. Problem Posing merupakan salah satu pendekatan pembelajaran nonkonvensional yang dalam proses kegiatannya membangun struktur kognitif mahasiswa. Proses ini dilakukan mahasiswa dengan cara mengaitkan skemata yang dimilikinya. Bahkan beberapa hasil penelitian memberikan gambaran, bahwa problem posing merupakan salah satu bentuk kegiatan dalam pembelajaran matematika yang dapat mengaktifkan mahasiswa, mengembangkan kemampuan berpikir mahasiswa dalam menyelesaikan masalah, dan menimbulkan sikap positif terhadap matematika
\end{abstract}

Kata Kunci : Problem Possing, Pembelajaran Matematika

\section{Pendahuluan}

Sejak diberlakukannya kurikulum 1975 hingga kurikulum 2013, telah banyak usaha yang dilakukan pemerintah maupun pakar pendidikan matematika dalam usaha meningkatkan prestasi belajar matematika bagi mahasiswa dan kemampuan mengajar dosen. Namun demikian, prestasi belajar mahasiswa pada umumnya masih rendah. Salah satu indikator yang dapat digunakan adalah posisi skor matematika SLTP Indonesia pada kompetisi internasional.

Pada saat ini telah diadakan berbagai kebijakan umum tentang pendidikan dasar dan menengah mengenai kurikulum baru yang disebut kurikulum 2013. Namun, masih dipertanyakan apakah kurikulum tersebut mampu mengatasi masalah pendidikan yang ada sekarang. 
Di Indonesia, nilai matematika berdasarkan hasil tes Trends in international Mathematics and science studi (TIMSS) 2003 yang dikoordinir oleh The international for Evaluation of Education Achievement (IEA) menempatkan mahasiswa Indonesia di peringkat 34 penguasaan matematika dan peringkat 36 penguasaan sains. Dibandingkan dengan dua Negara tetangga, Singapura dan Malaysia, posisi ini jauh tertinggal. Singapura berada pada peringkat, pertama, baik matematika maupun Sains, Malaysia peringkat 10 Matematika dan peringkat 23 bidang sains (Balitbang Depdiknas, 2004). Menurut hasil studi yang dilakukan oleh Suryanto dan Soemerset terhadap 16 SLTP pada beberapa propinsi di Indonesia juga menemukan bahwa hasil tes mata pelajaran matematika mahasiswa sangat rendah, utamanya pada soal cerita matematika (Upu, 2003). Masalah rendahnya nilai hasil belajar matematika mahasiswa, terutama pada soal cerita matematika harus segera diselesaikan, karena hal ini merupakan tugas dan tanggung jawab dalam dunia pendidikan. Mahasiswa harus dibekali dengan kemampuan menyelesaikan masalah matematika yang seharusnya menjadi hasil akhir dari proses belajar mengajar. Hal ini ditunjang dengan kurikulum berbasis kompetensi membagi penilaian matematika (khusus SLTP) ke dalam 3 bagian, yakni pemahaman konsep, penalaran dan komunikasi, dan pemecahan masalah. Dibalik rendahnya prestasi belajar matematika mahasiswa SLTP tersebut, kenyataan dilapangan justru menunjukkan mahasiswa pasif dalam proses pembelajaran. Sullivan (1992) (dalam Upu, 2003) mengatakan bahwa pembelajaran matematika di kelas pada umumnya hanya terpusat pada dosen, yang mengakibatkan mahasiswa menjadi malas dan kurang bergairah dalam menerima pelajaran. Dengan demikian dapat disimpulkan bahwa salah satu penyebab kurang berpartisipasinya mahasiswa dalam pembelajaran matematika di kelas, adalah pendekatan yang kurang tepat dalam mengaktifkan mahasiswa. Salah satu pendekatan yang mampu meningkatkan keterlibatan mahasiswa adalah melalui pendekatan Problem Posing (pengajuan masalah). Problem Posing merupakan salah satu pendekatan pembelajaran non-konvensional yang dalam proses kegiatannya membangun struktur kognitif mahasiswa. Proses ini dilakukan mahasiswa dengan cara 
mengaitkan skemata yang dimilikinya. Bahkan beberapa hasil penelitian memberikan gambaran, bahwa problem posing merupakan salah satu bentuk kegiatan dalam pembelajaran matematika yang dapat mengaktifkan mahasiswa, mengembangkan kemampuan berpikir mahasiswa dalam menyelesaikan masalah, dan menimbulkan sikap positif terhadap matematika (Anita, 2005).

Silver (dalam Upu, 2003) mengemukakan bahwa secara umum hasil penelitian tentang pengajuan masalah yang dilakukan oleh Brown dan Walter, 1990; Hashimoto, 1987; Healy, 1993; Keil, 1995; Skinner ,1991; VanDen Brink,1987; Winograd,1991; Perez,1986 dan Scoot,1997; menimbulkan dampak positif terhadap peningkatan kemampuan mahasiswa dalam memecahkan masalah matematika.

Adapun hal-hal yang akan dibahas pada tulisan ini adalah sebagai berikut:

1. Pengajuan masalah sebagai suatu pendekatan.

2. Pengajuan masalah sebagai suatu tujuan.

3. Penerapan Problem Possing.

\section{Pembahasan}

1. Pengajuan Masalah Matematika (Problem Posing)

Pengajuan masalah merupakan suatu pendekatan yang berkaitan dengan kemampuan dosen memotivasi mahasiswa melalui perumusan situasi yang menantang, sehingga mahasiswa dapat mengajukan pertanyaan matematika yang dapat diselesaikan dan berakibat kepada peningkatan kemampuan mereka dalam memecahkan masalah. Pengajuan masalah merupakan suatu tujuan yang berarti pengajuan masalah yang berkaitan dengan kompleksitas dan kualitas masalah matematika yang diajukan oleh mahasiswa berdasarkan situasi yang diberikan oleh dosen.

Terdapat beberapa definisi yang berbeda tentang pengajuan masalah matematika antara pakar yang satu dengan pakar yang lainnya dalam pendidikan matematika. Shukkwan (dalam Upu, 2003) mengartikan pengajuan masalah matematika sebagai perumusan ulang serangkaian masalah matematika dari situasi yang diberikan. Sedangkan Dillon (dalam Upu, 2003) mendefinisikan pengajuan masalah matematika sebagai problem finding, yaitu proses berpikir 
yang dihasilkan berupa pertanyaan matematika dari situasi tertentu yang diberikan untuk diselesaikan.

Silver melengkapi pengertian pengajuan masalah matematika, yakni sebagai suatu usaha mengajukan masalah baru dari situasi atau pengalaman yang telah dimiliki oleh mahasiswa. Silver (dalam Upu, 2003) menjelaskan bahwa dalam pustaka pendidikan matematika, pengajuan masalah matematika oleh mahasiswa mempunyai 3 pengertian, yakni:

1. Pengajuan masalah adalah perumusan masalah matematika sederhana atau perumusan ulang masalah yang telah diberikan dengan beberapa cara dalam rangka menyelesaikan masalah yang rumit.

2. Pengajuan masalah adalah perumusan masalah matematika yang berkaitan dengan syarat-syarat pada masalah yang telah dipecahkan dalam rangka mencari alternatif pemecahan masalah yang relevan.

3. Pengajuan masalah adalah merumuskan atau mengajukan pertanyaan matematika dari situasi yang diberikan, baik diajukan sebelum, pada saat, atau sesudah pemecahan masalah.

Berdasarkan pengertian di atas, pengajuan masalah dapat dilakukan dalam keadaan yang tidak terikat, dan pada akhirnya mahasiswa terbiasa dengan pengajuan masalah yang tepat dan benar, sehingga diharapkan dapat mengembangkan pola pikir matematikanya.

\subsection{Pengajuan Masalah sebagai Suatu Pendekatan}

Selanjutnya Silver menemukan bahwa pendekatan pengajuan masalah matematika merupakan suatu aktivitas dengan 2 pengertian yang berbeda, yakni: (1) proses mengembangkan masalah matematika yang baru oleh mahasiswa berdasarkan situasi yang ada dan (2) proses menformulasikan kembali masalah matematika dengan katakata mahasiswa sendiri berdasarkan situasi yang diberikan. Dengan demikian, masalah matematika yang diajukan oleh mahasiswa mengacu kepada situasi yang telah disiapkan oleh dosen.

Pengajuan masalah matematika menurut Brown dan Walter (dalam Upu, 2003) terdiri dari 2 aspek penting, yaitu accepting dan challenging. Accepting berkaitan dengan kemampuan mahasiswa memahami situasi yang diberikan oleh dosen atau situasi yang sudah ditentukan. Sementara 
challenging, berkaitan dengan sejauhmana mahasiswa merasa tertantang dari situasi yang diberikan sehingga melahirkan kemampuan untuk mengajukan masalah atau soal matematika. Hal ini berarti bahwa pengajuan masalah atau matematika dapat membantu mahasiswa untuk mengembangkan proses nalar mereka.

Dari beberapa pandangan di atas, maka dapat dikatakan bahwa pengajuan masalah matematika merupakan reaksi mahasiswa terhadap situasi yang telah disediakan oleh dosen. Reaksi tersebut berupa respons dalam bentuk pernyataan, pertanyaan non matematika atau pertanyaan matematika, terlepas dari apakah pertanyaan matematika tersebut pada akhirnya dapat dipecahkan atau tidak. Pertanyaan matematika tersebut mungkin berkaitan dengan situasi yang diberikan atau merupakan pengembangan dari situasi lain. Dengan demikian terdapat 3 unsur penting yang saling terkait dalam pembelajaran dengan pengajuan masalah matematika, yaitu (1) situasi masalah, (2) pengajuan masalah, dan (3) pemecahan masalah (Hamzah dalam Upu, 2003).

Menurut Suryanto (dalam Upu, 2003), kriteria pola pikir matematika dalam hubungannya dengan pengajuan masalah matematika meliputi:(1) memahami masalah, (2) keluar dari kemacetan, (3) mengidentifikasikan kekeliruan, (4) meminimumkan pekerjaan menghitung dan menulis, (5) tekun, (6) siap mencari jalan lain, dan (7) mengajukan masalah, soal atau pertanyaan. Pengajuan masalah atau soal matematika dapat dilakukan melalui gambar, benda manipulatif, permainan, teorema atau konsep, alat peraga, soal atau solusi dari soal itu sendiri.

Secara umum, pengajuan masalah atau pertanyaan oleh mahasiswa dalam proses pembelajaran, baik secara klasikal maupun secara kelompok merupakan aspek yang penting. Pengajuan masalah secara kelompok merupakan salah satu cara untuk membangun kerja sama yang saling menguntungkan. Dalam kaitannya dengan bekerja sama dalam kelompok belajar matematika, Goos, Galbraith dan Renshaw (dalam Upu, 2003) memberikan 3 pengertian yang berbeda. Pertama, parallel activity, artinya mahasiswa bekerja sama secara parallel dalam kelompok dengan sedikit pertukaran ide atau gagasan. Kedua, peer tutoring, mahasiswa mengerjakan soal secara bersama-sama dalam 
kelompok dan salah seorang mahasiswa yang lebih pintar menjadi pengendali jalannya kerjasam. Ketiga, collaboration, yang meliputi cooperative learning strategy (CLS). Strategi ini menuntut mahasiswa bekerjasama dalam kelompoknya terhadap masalah yang sama, dan tidak ada di antara mereka yang boleh mengerjakannya secara sendiri-sendiri. Pengajuan masalah matematika secara berkelompok dalam makalah ini mengacu kepada pengertian ketiga yang dikemukakan di atas. Hal ini dipilih berdasarkan pertimbangan bahwa yang menjadi tujuan utama dalam hal ini adalah kajian tentang perbedaan kemampuan mahasiswa dalam mengajukan dan memecahkan masalah secara klasikal dan kelompok, bukan tekhnik dalam bekerja sama pada kelompok. Senada dengan pengajuan masalah matematika secara kelompok, pengajuan masalah secara klasikal juga memiliki kelebihan. Pengertian secara klasikal yang dimaksud disini adalah proses pembelajaran yang berlangsung di dalam kelas, dengan seorang dosen sebagai fasilitator dan diikuti oleh semua mahasiswa didalam kelas. Selanjutnya, secara perorangan atau individu, mahasiswa mengajukan dan menjawab respons tersebut secara tertulis berdasarkan situasi yang telah diberikan oleh dosen.

Berikut pedoman bagi dosen dan mahasiswa dalam melaksanakan pendekatan pengajuan masalah menurut Surianto (dalam Upu, 2003):

\section{$>$ Bagi Dosen}

Posisi dosen dalam pembelajaran dengan pendekatan pengajuan masalah matematika adalah sebagai fasilitator dalam belajar. Selain itu, dosen berperan mengantar mahasiswa dalam memahami konsep dengan cara menyiapkan situasi sesuai dengan pokok bahasan yang diajarkan. Selanjutnya dari situasi tersebut, mahasiswa mengkonstruksi sebanyak mungkin masalah matematika dalam rangka memahami lebih jauh tentang konsep tersebut.

1) Dosen hendaknya selalu memotivasi mahasiswa untuk mengajukan atau memperluas masalah matematika.

2) Dosen hendaknya menyediakan beberapa situasi matematika yang berbeda-beda, berupa informasi tertulis, benda manipulatif, gambar, atau yang lainnya. 
91 | al-Khwarizmi, Volume II, Edisi 2, Oktober 2014, Hal. 85 - 94

3) Selanjutnya dosen melatih mahasiswa merumuskan dan mengajukan masalah, soal, atau pertanyaan matematika berdasarkan situasi yang diberikan.

4) Dosen dapat menawarkan masalah, soal, atau pertanyaan matematika yang berbentuk open-ended.

5) Dosen memberikan contoh cara merumuskan dan mengajukan masalah matematika dengan beberapa tingkat kesukaran, yang berkaitan dengan isi matematika maupun kesulitan bahasanya.

6) Dosen menyelenggarakan reciplokal teaching, yaitu pelajaran yang berbentuk dialog antara dosen dan mahasiswa mengenai materi pelajaran dengan cara menggilir mahasiswa berperan sebagai dosen.

\section{$>$ Bagi mahasiswa}

Student centered merupakan salah satu ciri dari pendekatan pengajuan masalah matematika. Mahasiswa seyogyanya berperan aktif mengajukan masalah matematika yang dapat terselesaikan, baik untuk dirinya sendiri maupun untuk mahasiswa lain.

1) mahasiswa diberi motivasi untuk merumuskan dan mengajukan sebanyak-banyaknya masalah, soal, atau pertanyaan matematika berdasarkan situasi yang telah diberikan.

2) Mahasiswa dibiasakan mengubah dan memvariasikan situasi yang diberikan menjadi masalah, soal, atau pertanyaan matematika baru sebelum mereka menyelesaikannya.

3) Mahasiswa dibiasakan untuk merumuskan dan mengajukan masalah, soal atau pertanyaan matematika serupa atau sejenis, setelah menyelesaikan masalah atau soal tersebut.

4) Mahasiswa harus diberanikan untuk menyelesaikan masalah, soal atau pertanyaan yang dirumuskan oleh temannya sendiri.

5) Mahasiswa diberi motivasi untuk menyelesaikan masalah, soal atau pertanyaan non rutin.

\subsection{Pengajuan Masalah sebagai Suatu Tujuan}

Pengajuan masalah bukan hanya sebagai suatu pendekatan dalam proses pembelajaran. Akan tetapi, lebih dari itu pengajuan masalah juga sebagai suatu tujuan yang ingin dicapai dalam proses pembelajaran. Misalnya, kemampuan pemahaman matematika mahasiswa dapat 
ditelaah melalui kemampuan mereka mengajukan masalah. Setiap respon yang diajukan oleh mahasiswa mempunyai tingkat keterselesaian yang berbeda menurut hubungan semantic dan struktur sintaksisnya. Silver dan Cai membagi pengajuan masalah dalam 3 bagian, yaitu (1) pertanyaan matematika, (2) pertanyaan non-matematika dan (3) pernyataan. Yang dimaksud dengan pertanyaan matematika adalah pertanyaan yang mengandung masalah matematika dan mempunyai kaitan dengan situasi yang diberikan. Pertanyaan matematika yang diamksud dibagi menjadi dua bagian, yaitu pertanyaan matematika yang dapat diselesaikan dan pertanyaan matematika yang tidak dapat diselesaikan.

Suatu pertanyaan matematika dikatakan dapat diselesaikan, jika pertanyaan tersebut memuat informasi yang cukup dari situasi yang ada untuk diselesaikan. Jenis pertanyaan ini dibedakan lagi menjadi dua bagian, yaitu pertanyaan matematika yang memuat informasi baru dan pertanyaan matematika yang tidak memuat informasi baru. Sedangkan pertanyaan matematika yang tidak dapat diselesaikan adalah pertanyaan yang tidak memuat informasi yang cukup dari situasi yang diberikan untuk diselesaikan. Pertanyaan matematika yang tidak dapat diselesaikan dapat juga berarti pertanyaan yang memiliki tujuan yang tidak sesuai dengan situasi yang diberikan. Pertanyaan non matematika adalah pertanyaan yang tidak mengandung masalah matematika dan atau tidak mempunyai kaitan atau hubungan dengan situasi atau informasi yang diberikan. Selain pertanyaan matematika dan pertanyaan non matematika, juga terdapat masalah atau soal yang diajukan oleh mahasiswa dalam bentuk pernyataan (statement). Jenis respon mahasiswa tersebut tidak mengandung kalimat pertanyaan yang mengarah kepada matematika atau non-matematika.

Contoh situasi:

Berkaitan dengan pokok bahasan dalil Pythagoras

Situasi:

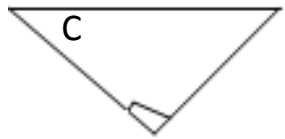

B 
Jenis respon yang mungkin diajukan oleh siswa:

- Apa itu sisi miring?

- ABC segitiga siku-siku

- Sisi miring segitiga $A B C$ adalah $A C$

- Apakah AB berhadapan dengan sudut $C$

- Apakah segitiga ABC siku-siku

- Sisi miringnya adalah BC

- Apakah AC = BC

- $A B C$ segitiga sama sisi

- $A B$ sisi miring karena $A C \perp B C$

- Mengapa disebut segitiga siku-siku

- Sisi miring adalah sisi yang terletak di depan sudut sikusiku

- Apakah segitiga siku-siku selalu punya sisi miring? Mengapa?

\section{Teori Belajar Pendukung Pendekatan Pengajuan Masalah}

Memperhatikan rangkain kegiatan yang terdapat pada pembelajaran dengan pendekatan pengajuan masalah matematika, maka terdapat paling sedikit 3 teori belajar yang mendasarinya, yakni:

1) Teori belajar Jean Piaget biasa juga disebut teori perkembangan intelektual atau teori perkembangan kognitif. Teori ini berkaitan dengan kesiapan anak untuk belajar, yang dikemas dalam tahap perkembangan intelektual dari lahir hingga dewasa.

2) Teori Jerome S. Bruner, utamanya yang berkaitan dengan dalil penyusunan dan dalil pengaitan. Bruner membagi perkembangan intelektual anak dalam 3 kategori, yakni enaktif, ikonik dan simbolik. Bruner mengemukakan 4 dalil yang penting dalam pembelajaran matematika, yakni: dalil penyusunan, dalil notasi, dalil pengkontrasan dan keanekaragaman, dan dalil pengaitan.

3) Teori belajar Robert M. Gagne, mengenai rangkaian verbal dan pemecahan masalah.

Pandangan Gagne tentang belajar dikelompokkan menjadi 8 tipe, yakni: isyarat (signal), stimulus respons, rangkaian gerak, rangkain verbal, memperbedakan, pembentukan konsep, pembentukan aturan, dan pemecahan masalah. 


\section{Penutup}

1. Kesimpulan

1) Pengajuan masalah sebagai suatu pendekatan terdiri dari 2 pengertian:

a. Proses mengembangkan masalah matematika yang baru oleh mahasiswa berdasarkan situasi yang ada.

b. Proses memformulasikan kembali masalah matematika dengan kata-kata mahasiswa sendiri berdasarkan situasi yang diberikan.

2) Pengajuan masalah sebagai suatu tujuan meliputi pengertian bahwa kemampuan pemahaman matematika mahasiswa merupakan kemampuan mereka menjawab masalah yang berupa pertanyaan matematika, pertanyaan non matematika dan pernyataan.

\section{Saran}

Diharapkan kepada dosen untuk dapat menggunakan pendekatan problem possing dalam pembelajaran karena pendekatan ini dapat membantu mahasiswa untuk mengembangkan proses nalar mereka. Sehingga diharapkan dapat mengembangkan pola pikir matematikanya.

\section{Daftar Pustaka}

Anita. 2005. Peningkatan Kemampuan Menyelesaikan Masalah Matematika melalui Pendekatan Problem Posing Mahasiswa Kelas IA SMP Khadijah Makassar. Skripsi tidak diterbitkan. Makassar : FMIPA UNM.

Upu, Hamzah. 2003. Problem Posing dan Problem Solving dalam Pembelajaran matematika. Bandung : Pustaka Ramadhan.

Suherman, Erman. 2003. Strategi Pembelajaran Matematika Kontemporer. Bandung: Universitas Pendidikan Indonesia. 